\title{
人材育成の観点から見た福島第一原子力発電所の過酷事故対応の教訓
}

\author{
吉澤 厚文*1，大場 恭子*2，北村 正晴*3
}

\section{Lessons learned from emergency response during severe accident at Fukushima Daiichi nuclear power plant viewed in human resource development}

\author{
Atsufumi YOSHIZAWA*1, Kyoko OBA*2 and Masaharu KITAMURA*3 \\ ${ }^{* 1}$ Research Center for Safe and Secure Society, Nagaoka University of Technology \\ 1603-1 Kamitomiokamachi Nagaoka-shi, Niigata 940-2188, Japan \\ ${ }^{* 2}$ Japan Atomic Energy Agency \\ 2-2-2 Uchisaiwai-cho, Chiyoda-ku, Tokyo 100-8577, Japan \\ ${ }^{* 3}$ Research Institute for Technology Management Strategy (TeMS) Co., Ltd. \\ 6-6-40-403 Aobaaramaki-aza, Aoba-ku, Sendai-shi, Miyagi 890-8579, Japan
}

Received: 11 June 2017; Revised: 17 August 2017; Accepted: 4 October 2017

\begin{abstract}
This research aims to develop capability of on-site staffs that can respond to beyond "design basis accident (DBA)" in the sophisticated socio-technical system, in which ensuring safety has been more complicated. Fukushima Daiichi nuclear accident is therefore considered as the actual case of "beyond DBA". The authors focused on the actions to prevent the accident progression undertaken by on-site staffs, which were hardly evaluated in existing accident analyses and reports. With reference to the concept of resilience engineering, "Responding" of the four cornerstones was particularly analyzed. Based on the precedent studies, causal factors of modeling "Responding" where pointed out the importance of "Attitude" that is a new lesson learned from on-site response at the accident. In addition, new lessons learned on improvement of skills indicated the limit of the concept of risk removal type safety as a safety goal that human is defined as "a safety hazard element". This led the necessity of the success expansion type of safety as a new safety goal that human is defined as "a resource necessary for system flexibility and resilience". Focusing on "Responding" on-site enabled to deduce core competence by extracting causal factors. Thus, new lessons learned successfully derived introduced for human resource development of the next generation to lead technologies in the society.
\end{abstract}

Keywords : Fukushima Daiichi nuclear power plant, Severe accident, Resilience egineering, Four cornerstones, Responding, Attitude, Skill, Accident management, Human resource development

\section{1. 緒言}

東京電力株式会社（以下，東京電力）福島第一原子力発電所の事故（以下， $1 \mathrm{~F}$ 事故）後の報道，あるいは強化 された原子力規制等に表れている通り，1F 事故は，技術が社会に受容される（例えば，必要なものとみなされ稼 働すること）上で必要とする安全レベルを，改めて考えさせる事象となった.

こうした中，技術が社会に受容されるために，有していなければならない安全を，「許容不可能なリスクから解 放されていること」(the International Organization for Standardization and the International Electrotechnical Commission: ISO/IEC, 2014）に基づいて考えれば，「許容不可能なリスクがない」と社会に判断される安全の保有が最低限の条 件となろう。しかし，社会が，何をもって「許容不可能なリスクがない」と判断するかは，時代や環境，情勢等

\footnotetext{
No.17-00263 [DOI:10.1299/transjsme.17-00263], J-STAGE Advance Publication date : 17 October, 2017

*1 正員，長岡技術科学大学安全安心社会研究センター ( $940-2188$ 新潟県長岡市上富岡町 1603-1)

*2 正員, 日本原子力研究開発機構（干100-8577 東京都千代田区内幸町 2-2-2）

*3 TeMS 研究所（干890-8579 宮城県仙台市青葉区青葉新巻字 6-6-40-403）

E-mail of corresponding author: atsufumi-yoshizawa@japc.co.jp
} 
によって変化している．他方，「現代のリスクは，予見可能性，相互依存性などの観点から，未然防止が困難で あり, かつ発生可能性をゼロにすることは現実的ではない」との指摘もなされている (産業競争力懇談会, 2013). よって, 安全の担い手でもある技術の担い手には, 常に「許容不可能なリスクがない」と判断される安全の実現 を目指し，社会に受容されるように，あるいは受容された後もリスクの低減化を図る必要と同時に，リスクの想 定内外にかかわらず, リスクが顕在化した時に対応できる能力を向上させる必要がある.

$1 \mathrm{~F}$ 事故に際し, 日本機械学会の福島第一原子力発電所事故からの教訓に学ぶ工学の原点と社会的使命検討委員 会は, 報告（日本機械学会，2012，以下，機械学会報告）をまとめている．その中で，学会は，会員に「認識科 学に立脚した設計科学」と「技術の社会技術化科学」の両方の視点に立脚した機械工学研究・教育と社会貢献を 求め, これらをより具体的に人材育成という視点で検討した結論として, (A)「認識科学に立脚した設計科学」に 指摘されるような技術システムに想定されるリスクの下で，システムが正常に作動するべく適切な設計基準を作 成および実行する能力，Bこの設計基準を超えた残存リスクが顕在化しても受け入れがたい損害が発生しないよ うな対応ができる能力， C「技術の社会技術化科学」で求められているような(AおよびBを社会が理解するため

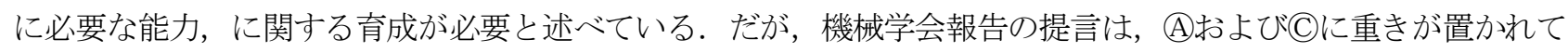
おり，Bについては「設計基準を超えた残存リスクが顕在化しても受け入れがたい損害が発生しない」ようにす るための対策について，「損害防止・軽減措置のバックアップ措置が必要となる場合もある。このような対策を繰 り返すことにより，最後に残存リスクが受け入れ可能なレベルになるはずである.」と述べるに留まっている.

一方, $1 \mathrm{~F}$ 事故前の福島第一原子力発電所は, 設計基準を超えた残存リスクが顕在化した時の対応を全く行って いなかったわけではない. 福島第一原子力発電所でも, 設計基準を超えた残存リスクが顕在化した事象を想定し, ハードおよびソフト対策を行っていた。しかし， $1 \mathrm{~F}$ 事故は，「それらの想定を超えた残存リスクが顕在化した設 計基準外事象（以下，想定を超えた設計基準外事象）」であった. 事故の収束を目指した対応は, 設計基準外事象 が起きた時のために用意してあった非常用の機器等, 損害防止・軽減措置のバックアップ措置も機能不全になる 中で行われた。 これに対し, 機械学会の報告書にある「損害防止・軽隇措置のバックアップ措置が必要となる場 合もある.このような対策を繰り返すことにより, 最後に残存リスクが受け入れ可能なレベルになるはずである.」 との考えは，設計基準を超えた残存リスクが顕在化した状況は想定できることを前提に，損害防止・軽減措置の バックアップ措置を求めているように受け取れ，それらをしても尚起き得る可能性を否定できない「想定を超え た設計基準外事象」というリスクへの対応力についての検討は明示的になっていない. 科学技術の高度化・複雑 化が進み，リスクの予見も難しさが増す中，人材育成においてもリスクを想定しそれに対応するだけではなく，

「想定を超えた設計基準外事象」が起きても，受け入れがたい損害が発生しないようにする対応能力の向上とい った視点が必要ではないだろうか.

本研究は，技術が社会に受け入れられるために必要となる人材の育成を目指し，「認識科学に立脚した設計科 学」の視点と「技術の社会技術化科学」の視点に加えて,「設計基準を超えた残存リスクが顕在化しても受け入れ がたい損害が発生しないような対応ができる能力」を備える人材育成について提言を行うものである．想定を超 えた設計基準外の残存リスクが顕在化し，過酷事故に至った事例である $1 \mathrm{~F}$ 事故に着目し，システムが受けたダ メージから回復するための指針を示すレジリエンスエンジニアリングの考え方（Hollnagel and Woods, 2006）を参 照して, 事故進展を防いだ行為群の中から, 技術システムの安全を担う人および組織に必要な要件に関する教訓 を導出する.

\section{2. 方 法}

\section{$2 \cdot 1$ 事実関係のデータソース}

本研究における事実関係の整理にあたっては, 関係者の意見聴取やプラントデータ等にアクセスが可能な形で 作成されている東京電力の福島原子力事故調查報告書（東京電力株式会社，2011，2012a，以下，東電事故調）, 東京電力福島原子力発電所における事故調查 - 検証委員会の報告書（東京電力福島原子力発電所における事故調 查・検証委員会, 2011，2012a，以下，政府事故調），および東京電力福島原子力発電所事故調查委員会の報告書

(東京電力福島原子力発電所事故調査委員会, 2012, 以下, 国会事故調) を用いた. また, 学術的な評価として, 
日本原子力学会（日本原子力学会，2014，以下，学会事故調），並びにそのヒューマン・マシン・システム研究 部会の報告書（日本原子力学会ヒューマン・マシン・システム研究部会, 2015, 以下, HMS 報告）を参照した.

さらに，上記の報告書の公開後，新たに公開されたデータである，テレビ会議の発話内容 (宮崎知己他，2013， 以下, TV 会議), 当時発電所長であった吉田の政府事故調査委員会による聴取結果 (政府事故調査委員会, 2011a, $2011 b$ ，以下，吉田調書）（参照日 2016 年 11 月 23 日），東京電力の未解明問題に対するその後の調査結果（東 京電力株式会社，2015，以下，未解明調査）（参照日 2016 年 11 月 23 日）も反映している.

\section{2 - 2 事象の選定と整理}

1 章でも述べたが，本研究では，「設計基準を超えた残存リスクが顕在化しても受け入れがたい損害が発生し ないような対応ができる能力」を持つには，システムの挙動のすべては把握できないという前提に立ち，時に想 定を超えた設計基準外事象が起きても，受け入れがたい損害が発生しないような対応ができる能力を備えること が必要と考えている. そのため, 実際の「想定を超えた設計基準外事象」となった現場で, どのような行為がな されたかを分析し，教訓抽出を試みる.

一方，適切な分析を行うには，現場でどのような行為がなされたかを把握できる利用可能なデータが存在して いなければならない。これらの条件から, 分析対象を, 全交流電源表失後, 炉心溶融や水素爆発を起こしながら も，最終的に一時中断した炉心几の注水を回復し，冷却能力を確立した 3 号機の事象とした. 3 号機は，原子炉 への注水停止（13 日 2:42）から，13 日 13:12 までに原子炉への注水を暫定的に回復することに成功しており，こ の間及び関係する現場の行為については, 利用可能なデータが多く存在している. 事象は, 機器の状態遷移をま とめた上で，イベントツリーにて整理した.

\section{$2 \cdot 3$ レジリエンスエンジニアリングの視点}

レジリエンスエンジニアリングとは，2006 年に E. Hollnagel や D. Woods らを中心とするメンバーがまとめた “Resilience Engineering: Concepts and Precepts”に始まりをもつ，ヒューマンファクターの分野から誕生した言葉で ある.レジリエンスは，「弾力性」や「復元力」「回復力」と訳されるが，その言葉からも解るとおり，目指すべ き安全を「物事が起こらない状態を守ること」に留めず,「時にその状態から逸脱する大きなストレスを受けても， 可能な限りその影響を小さくし，破局を避けること」という概念に広げていることも特徵である（Hollnagel and Woods, 2006)。このような特性を高めるために，レジリエンスエンジニアリングでは，良好事例への着目と，4つ のコア能力 (Learning : 学習できる, Responding : 対処できる, Monitoring : 監視できる, Anticipating : 予見でき る）を重視している（Hollnagel, 2011）。また，レジリエンスエンジニアリングは，絶えず変動しているシステム が，受けた変動を吸収しシステムの動作目的を継続できる，変動に対し性能は低下させても動作は継続できる， 破局的な状態は回避できる, 状況が回復したら速やかに元の状態またはそれに蕉じた状態に復旧できる，という ダイナミックな特性（レジリエント特性）を獲得するための方法論として位置付けられている（北村，2014）.

本研究では, 前述した事象進展のイベントツリーに, 既存の事故調査で着目する行為, レジリエンスエンジニ アリングの視点に基づき分析した時に着目する行為を追記することで, 着目する行為の違いを明確にした. なお, 本研究においては，「行為」は現場で実施された行動であり，「事象」はプラント毎に特定の目的に対して実施 された一連の行為及びこれに関連した機器の動作の結果（例えば，3 号機の原子炉への注水，格納容器ベント， など）を称している.

\section{3. 結 果}

\section{$3 \cdot 1$ 事象の整理}

東電事故調および政府事故調に記載された関連記述を参照し，本事象に係るプラントの機能とその略式名称， 及びその機能の津波後の状況を表 1 にまとめた。津波による物理的破壊や交流電源の喪失で，多くの機器の機能 が失われ，限定された機器（リソース）で対応しなければならない過酷事故対応の現場の状況が示されている. さらに, 個々の事象の成功または失敗の生起順序に従ってイベントツリー形式に整理した結果を図 1 に示す. 地 震発生時の状況を初期值とすることで， 3 号機の震災後の推移と， 1 号機，6 号機の推移の違いを明示した. 1 号 
機は，交流電源・直流電源ともに使用不能となり，3 号機で使用可能であった高圧注水系に相当する機能を持つ 機器を十分に稼働することができず，原子炉の冷却機能が早期に失われたため， 3 号機よりも早い段階で炉心損 傷に至っている. 一方， 6 号機は非常用電源が津波の被害を免れ利用可能であったため，この電源を利用寸るこ と等で原子炉冷却機能を確立し，炉心損傷に至ることなく停止に成功している.

Table 1 Status of unit 3 related functions of injecting water into the reactor core after the tsunami attack

This table shows physical destruction and the loss of AC power supply due to the tsunami led to the loss of many functions of the equipment designed in advance, and it was necessary to deal with only limited equipment available on site.

\begin{tabular}{|c|c|c|c|c|c|c|}
\hline Objective & Facility Name & Abbreviation & Main Function & $\begin{array}{l}\text { No. of } \\
\text { Systems }\end{array}$ & $\begin{array}{l}\text { Not } \\
\text { Requiring } \\
\text { AC Power }\end{array}$ & $\begin{array}{l}\text { Status after } \\
\text { Tsunami* }\end{array}$ \\
\hline \multirow{2}{*}{$\begin{array}{l}\text { High Pressure } \\
\text { Water Injection }\end{array}$} & \begin{tabular}{|l} 
高圧注水系(High Pressure \\
Coolant Injection System)
\end{tabular} & HPCI & $\begin{array}{l}\text { HPCI is one of the systems of the emergency core cooling system } \\
\text { capable of injecting cooling water into the reactor by means of steam } \\
\text { turbine driven high pressure pump when there is an accident involving a } \\
\text { relatively small pipe rupture so that the reactor does not undergo rapid } \\
\text { decompression. }\end{array}$ & 1 & 0 & $\begin{array}{l}\text { Operates on } \\
\text { DC power }\end{array}$ \\
\hline & $\begin{array}{l}\text { 原子炉隔離時冷却系 (Reactor } \\
\text { Core Isolation Cooling System) }\end{array}$ & RCIC & $\begin{array}{l}\text { RCIC is the system for removing fuel decay heat by injecting coolong } \\
\text { water into the reactor using turbine driven pump running on reactor } \\
\text { steam in case the main condensor becomes inoperable. The RCIC pump } \\
\text { flow rate is relatively small, approximately one tenth that of the HPCI. }\end{array}$ & 1 & 0 & $\begin{array}{l}\text { Operates on } \\
\text { DC power }\end{array}$ \\
\hline \multirow{2}{*}{$\begin{array}{l}\text { Alternate High } \\
\text { Pressure Water } \\
\text { Injection }\end{array}$} & $\begin{array}{l}\text { 制御棒駆動系（Control Rod } \\
\text { Drive） }\end{array}$ & CRD & $\begin{array}{l}\text { CRD is the facility used for withdrawing and inserting control rods in } \\
\text { order to control the reactor power. Also, in case of emergnecy, it can be } \\
\text { operated by means of an automated reactor protection system signal to } \\
\text { quickly insert the control rods into the reactor . }\end{array}$ & 1 & & $\begin{array}{l}\text { Loss of } \\
\text { function }\end{array}$ \\
\hline & $\begin{array}{l}\text { ホウ酸水注入系 (Stand by } \\
\text { Liquid Control System) }\end{array}$ & SLC & $\begin{array}{l}\text { SLC is the system used as a backup to control rods whereby sodium } \\
\text { borate solusion which has high capacity for neutron absorption is } \\
\text { injected into the reactor to stop the reaction in case of the control rods } \\
\text { fail to insert for whatever reason while the reactor is in operartion. }\end{array}$ & 2 & & $\begin{array}{l}\text { Loss of } \\
\text { function }\end{array}$ \\
\hline $\begin{array}{l}\text { Pressure } \\
\text { Reduction }\end{array}$ & $\begin{array}{l}\text { 逃がし安全弁 (Safety Relief } \\
\text { Valve) }\end{array}$ & SRV & $\begin{array}{l}\text { SRV allows steam to escape into the suppression chamber in order to } \\
\text { protect the pressure vessel in the case that the reactor pressure rises } \\
\text { abnormally high, and in addition, it also functions as an emergency core } \\
\text { cooling system and an automatic depressurization system. }\end{array}$ & 8 & 0 & $\begin{array}{l}\text { Operates on } \\
\text { DC power }\end{array}$ \\
\hline \multirow{2}{*}{$\begin{array}{l}\text { Low Pressure } \\
\text { Water Injection }\end{array}$} & $\begin{array}{l}\text { 炉心スプレイ系（Core Spray } \\
\text { System） }\end{array}$ & CS & $\begin{array}{l}\text { CS is a type of an emergency core cooling system that in case of loss of } \\
\text { coolant accident, coolong water is sprayed from the upper part of the } \\
\text { reactor core. }\end{array}$ & 2 & & $\begin{array}{l}\text { Loss of } \\
\text { function }\end{array}$ \\
\hline & $\begin{array}{l}\text { 残留熱除去系（Residual Heat } \\
\text { Removal System） }\end{array}$ & RHR & $\begin{array}{l}\text { RHR is one of the sub-systems of emergency core cooling systems for } \\
\text { cooling the coolant removing fuel decay heat and for regulating the } \\
\text { reactor water level by injecting cooling water into the reactor in } \\
\text { emergencyes. }\end{array}$ & 2 & & $\begin{array}{l}\text { Loss of } \\
\text { function }\end{array}$ \\
\hline \multirow{3}{*}{$\begin{array}{l}\text { Alternate Low } \\
\text { Pressure Water } \\
\text { Injection }\end{array}$} & $\begin{array}{l}\text { 復水補給水系(Make-up Water } \\
\text { System(Condensate) })\end{array}$ & MUWC & $\begin{array}{l}\text { MUWC is the system for supplying various kinds of water needed for } \\
\text { operation of the power station via pumps. Its purpouse is not for } \\
\text { emergency use, but from the stand point of acident management(AM), it } \\
\text { can be used for injection of cooling water into the reactor. }\end{array}$ & 1 & & $\begin{array}{l}\text { Loss of } \\
\text { function }\end{array}$ \\
\hline & $\begin{array}{l}\text { 消火系（電動駆動）（Fire } \\
\text { Protection System） }\end{array}$ & FP & $\begin{array}{l}\text { FP is installed inside the power stations with the motor driven pump and } \\
\text { is capable of injecting cooling water into the reactor as a part of accident } \\
\text { management(AM). }\end{array}$ & 1 & & $\begin{array}{l}\text { Loss of } \\
\text { function }\end{array}$ \\
\hline & $\begin{array}{l}\text { 消火系(ディーゼル駆動) } \\
\text { (Diesel Driven Fire Pump) }\end{array}$ & DDFP & $\begin{array}{l}\text { DDFP is automatically start up when FP motor driven pump cannot be } \\
\text { operated. }\end{array}$ & 1 & 0 & $\begin{array}{l}\text { Operates on } \\
\text { DC power } \\
\text { Diesel Driven }\end{array}$ \\
\hline $\begin{array}{l}\text { Self-protection } \\
\text { Fire Fighting }\end{array}$ & Fire Engine & - & $\begin{array}{l}\text { Fire engines were distributed to strengthen in-house fire brigade } \\
\text { framework, as a result of lessons learned from the response to the } \\
\text { transformer fire during the Niigata-Chuetsu-Oki Earthquake which } \\
\text { occurred in July } 2007 \text {. }\end{array}$ & 3 & 0 & $\begin{array}{l}\text { Engine } \\
\text { Driven, only } \\
\text { one out of } 3 \\
\text { is available }\end{array}$ \\
\hline
\end{tabular}

* : "Loss of function" means not only loss of power supply but also loss of other equipment functions at once. 
イベントツリーを用いて 3 号機の注水に係る推移を説明する. 文章中の番号は, 図 1 に記載してある番号に 該当するものであり，後述するレジリエンスエンジニアリングにより着目する行為群を示す．

はじめに, 行為群(1)ついて述べる. 震災直後, 表 1 に示した通り 3 号機は全交流電源喪失状態となった（3 月 11 日 15:42 原子力災害対策特別措置法第 10 条通報事象）。しかしながら，直流電源が使用可能であったこと から，これによる運転が可能な高圧注水系にて，原子炉への注水が実施された。 この行為群ではその間に SLCの 復旧を試みたが, 1 号機の爆発で電源ケーブルが損傷し, 復旧が不可能となり断念している. 行為群(2は, 長期 に亘る高圧注水系の維持である，これは，高圧注水系を運転するうえで必要な直流電源の延命策をさまざま講じ た結果として可能となったものである. 行為群(3)は, 高圧注水系の停止である. 原子炉の崩壊熱の減衰により原 子炉圧力が低下傾向となり, HPCI の運転領域を超えた状態となっていたこと等から, 運転員は 13 日 2:42 に当該 系統を手動停止した. 低圧注水系の復旧は目途が立たない状況であったため, 運転員は直ちに原子炉減圧を行い, アクシデントマネジメントとして整備されていた DDFPによる低圧代替注水に切り替えようとしたが，系統の切 り替えが間に合わず， SRV による減圧も直流電源が不足しており作動しなかったことから，この時点で注水が 中断する事態となった。 その後, 行為群(4)により, 低圧代替注水は, DDFP や消防車により確立され, 行為群(5) では，社員の車のバッテリー等を集め SRV の復旧対応（8:58 頃複数弁が作動）を実施している．主に行為群(4), (5により，低圧代替注水の実施（9:08 より），淡水から海水への水源の切り替えによる継続的な原子炉への注水 機能の回復（13:12）が達成された.

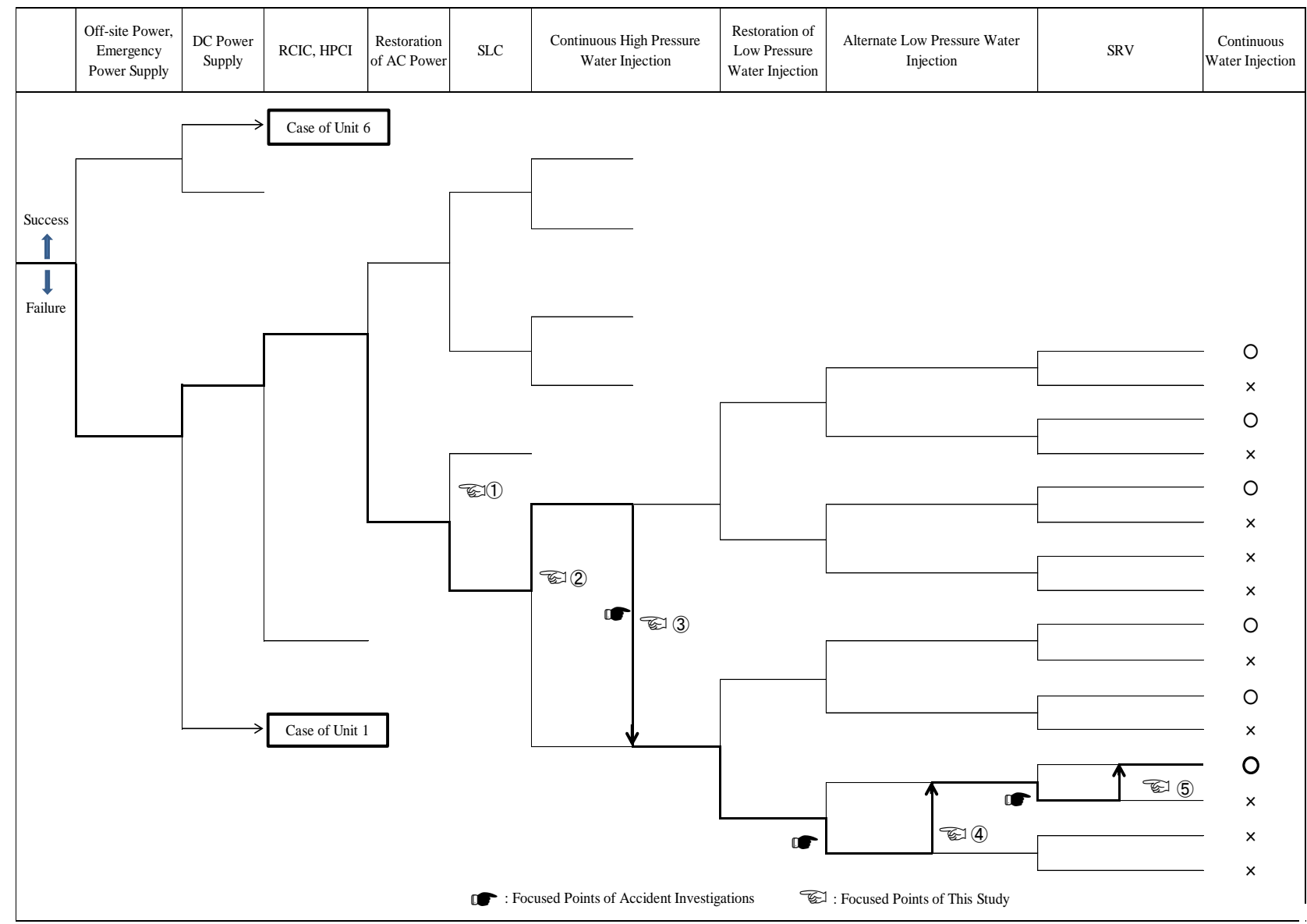

Fig. 1 Event tree of unit 3 restoration of the reactor core water injection system and differences of the focused events between accident investigation reports and this research

Analysis of the event tree shows both of the success and the failure groups of actions including in the unit 3 events. In addition, this analysis represents the difference between focused events taken from the accident investigations and this research on resilience engineering aspect. Event tree after the earthquake also clarifies the differences between other units. 
図 1 のイベントツリーによる整理により, 現場の行為には, 成功と失敗の両方が含まれていることが示されて いる. その中で，レジリエンスエンジニアリングで着目する行為群として抽出した各行為は，(2), (4), (5)が注水 を成功に導いた行為群, (1)は信頼性の高い機器による注水を実現するための行為群（結果は伴わなかったが, ダ メージからの回復を目指寸状況において, 機器の信頼性に優先順位をおいた判断は適切であることから注目した), (3)注水に関しては失敗につながっているものの, 機器の保護に注目した評価では成功といえる行為群, である.

図 1 に, これらの行為群と, 事故調査報告書において取り上げられている行為群を合わせて示すことで, 原因究 明による再発防止を目的とする事故調査報告書と, 成功や回復に係る行為群にも着目するレジリエンスエンジニ アリングの視点を用いた本研究の違いを明確にすることができた.

\section{2 “Responding” を発揮する背後要因の抽出}

レジリエンスエンジニアリングの 4 つのコア能力の中で, 現場で注目すべきものは「Responding: 対処できる」 となる。ここでは, 先行研究の調査並びに第一筆者の事故現場の体験に基づいて作成した Responding の背後要因 の構造化モデル（図 2）（Yoshizawa et al., 2016）を用いて，図 1 で示したレジリエンスエンジニアリングの視点 を用いた本研究が着目した行為群の背後要因を抽出し，分析を行う。なお， Responding は個人で発揮されるもの や組織として発揮されるものも存在する. 本研究で分析を行った $1 \mathrm{~F}$ 事故のデータソースは, 基本的に組織とし ての Responding を発揮した結果を示したものとなっているため，本研究の分析も組織を基本とするが，個人とし ての評価を行っているものは，その旨補足を行う。

(1) “Responding”の背後要因に関する先行研究

レジリエンスエンジニアリングの領域で Responding についての具体的な背後要因を指摘している先行研究と して, Erik Hollnagel の RAG（Resilience Analysis Grid）（Hollnagel, 2014），Jouko Heikkiläのレジリエンス向上特性 (Resilience Enhancing Properties) (Heikkilä et al., 2010) , 小松原の RMS (Resilience Management System) (Komatsubara, 2011）がある.たとえば，Hollnagel は，RAGの中でそれぞれの能力を探るための質問群によりレジリエンスの測 定を試みており，Respondingについては，検知，認識，対処の方法と力量，リソースといった内容を重視してい る.また, Heikkilä は, レジリエンスの能力一般として, 知識とスキル (Capability), 前向きに対処する姿勢

(Motivation)，リソースや環境（Condition）の必要性を指摘している.さらに，小松原は，1F 事故も踏まえ管理 すべき要因として, 前向きな態度 (Positive Attitude)， スキル (Technical Skill, Non-technical Skill), 健康 (Mental and Physical Health）を提案しており，Resilience Resourceの必要性も指摘している.

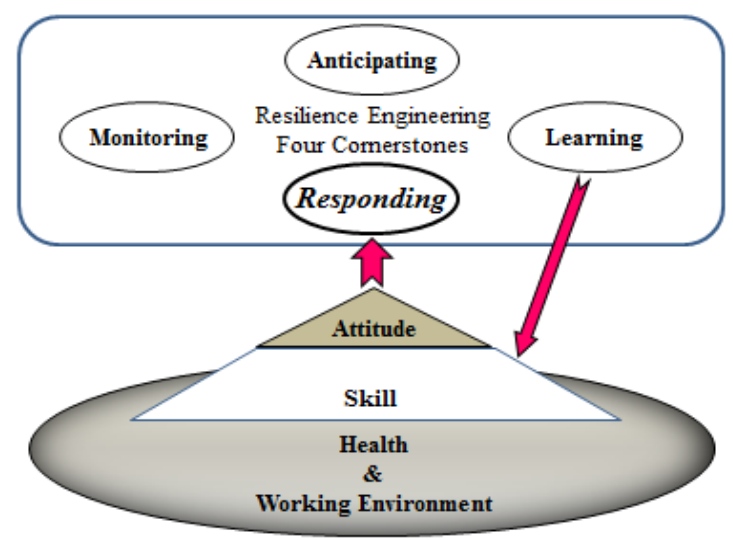

Responding: Responding to events Learning: Learning from past experiences Anticipating: Anticipating threats and opportunities

Monitoring: Monitoring event progression Attitude: Attitude and sense of responsibility that seeks out change in a positive manner

Skill: Technical and non-technical skills including knowledge and recognition

Health: Emotional and physical health

Working Environment: Resources, habitability, operational pressure and other elements

Fig. 2 Hypothetical model of causal factors of "Responding"

"Responding", one of the Four Cornerstones of Resilience Engineering, is set up from the investigation of previous studies and on-site experiences at Fukushima accident. This model shows those important factors to enhance and to manage organizational resilience. 
(2) “Responding”の背後要因に関するモデルの作成

先行研究の調査から, Respondingの背後要因として指摘されているものは, 表現は異なっているものの, 共通 した要素も多いことが示された. 本研究では, Responding を生む背後要因を, Attitude, Skill, Health, Working Environment としてまとめた.

各要因について説明する，一般的に，有効な Responding を発揮するには，知識・認知や技能が必要であること は, 組織が，Responding を発揮して欲しいと考える対象者に対して教育・訓練等を行っていることからも理解で きよう。ここでは，「知識や認知を含めた技能」を“Skill”とした． Skill は，レジリエンスエンジニアリングの 4 つのコア能力の Learning に基づくところが大きい.「想定を超えた設計基準外事象」における Responding を考 えた場合，この Skill をある程度備えていることは基本であり，ここでの分析はこれを前提とする．しかし， Skill を有している個人・組織であっても, 対応姿勢が久けていれば Responding の発揮は生まれない. したがって Respondingに直接関与する要因として, Skill を備えた個人・組織の「対応姿勢」が重要となる. 背後要因モデル の Attitude とは，このような姿勢を示すもので，「困難な状況下においても前向きに対処する姿勢，使命感」と定 義できる.

一方, Responding の発揮をより確実にしていくうえで重要な要因には, 個人の Health および組織が担う Working Environment がある。これらは，いかに充実していたとしても，Skill および Attitude がなければ Responding の発 揮は生まれないが，「想定を超えた設計基準外事象」が㫫在化した厳しい状況の中で, Responding が発揮されるに は，技術システムの安全を担う組織が「Skill やAttitude を支える要因」であるこれらについても理解し，醸成す べきであろう．Working Environment は，小松原が指摘する Resilience Resource（食料，水，トイレ，通信手段や ロジスティック，作業に必要な設備や用具等）に加え, 第一筆者の $1 \mathrm{~F}$ 事故対応の経験から得た実感として得た, 明るさ, 気温等といった環境居住性, 放射線防護, 而震などの作業者の安全を確保する建物の堅牢性, 職務に対 寸る時間的・外的圧力などの総称とした. 図 2 は, Respondingに対するこれらの要因の貢献について, 具体的な 関係性を構造化したモデルである.

図 1 に示した, レジリエンスエンジニアリングの視点で抽出した着目すべき行為群(1)（5)の背後要因のうち， 図 2 にモデル化された要因の, Skill 並びに Working Environment を表 2 によとめた. 表 2 は, 非常用の機器等, 損害防止・軽減措置のバックアップ措置も機能不全になる現場において, 注水の回復がどのような Responding に よって実現され，またそれらの背後要因がどのようになっていたかをまとめたものである，なお， Respondingの 発揮を生む残りの要因のうち, Attitudeについては, 既存の事故調査報告において指摘はされていても，それらの 指摘は個々の Responding ではなく，全体の Responding の発揮に対するものであることから，表 2 の整理からは 除外し, 次章にて分析する. また, Healthについては, 事故後に現地に入った医師らによる報告 (佐野他, 2012) から現場では大変厳しい状況であったことが想定されるが, 現時点で入手可能なデータでは Responding との関連 を明確にすることは困難であるため, 本研究の分析対象からは除外した.

Table 2 Classified results of the focused events based on Hypothesis of causal factors of "Responding"

This table summarizes "Skill" and "Working Environment" as the causal factors of the focused "Responding" (1) to (5), which are selected from the aspect of resilience engineering showed in Fig. 1.

\begin{tabular}{|c|c|c|c|}
\hline $\begin{array}{c}\text { Events } \\
\text { (The number represents action } \\
\text { numbers in Figure 2) }\end{array}$ & Responding & Skill & Working Environment \\
\hline $\begin{array}{l}\text { DSLC recovery } \\
\text { Efforts for ensuring alternative } \\
\text { methods of reliable high pressure } \\
\text { water injection, even though it } \\
\text { failed }\end{array}$ & $\begin{array}{l}\text { *As a result of equipment damage verification at Unit } 4 \text {, a cable was installed by using } \\
\text { applicable power panel and thermal cutting of walkway shielding door connecting a power } \\
\text { supply car. [TEPCO Report] } \\
\text { *Low pressure alternative water injection was also maintained until SRV was operated. } \\
\text { [TEPCO Report] } \\
\text { *Due to water shortage, MUWC water source system was planned to be restored at the same } \\
\text { time. (However, it failed to use because Unit } 1 \text { hydrogen explosion damaged the cable.) ITV } \\
\text { Conference】 }\end{array}$ & $\begin{array}{l}\text { *Decision to use SLC as an alternative high-pressure injecting } \\
\text { water } \\
\text { *Utilization of Unit } 4 \text { equipment } \\
\text { *Damage verification of Unit } 4 \text { equipment } \\
\text { *Cable installation connecting a power supply car (Ex.Thermal } \\
\text { cutting of shielding door) } \\
\text { "Restration plan for both of water source MUWC and SLC }\end{array}$ & \begin{tabular}{|l} 
Advantage \\
*Seismic Isolation Building was available (The following \\
events are in common.) \\
*Power supply car (procured), cable (partly procured) \\
*Thermal cutting devise for shielding door (resource \\
from a subcontracting company) \\
*Station blackout manual was available (Preconditions \\
that monitoring function must have been maintained.) \\
Disadvantage \\
*Debris brought by tsunami (The following events are in \\
common.) \\
*Outside work after Unit 1 hydrogen explosion (The \\
following events are in common) \\
*Two employees were missing (The following events are \\
in common) \\
*Unit 3 relevant equipment was disabled. \\
*Power supply cable was damaged due to the explosion \\
of Unit 1.
\end{tabular} \\
\hline
\end{tabular}




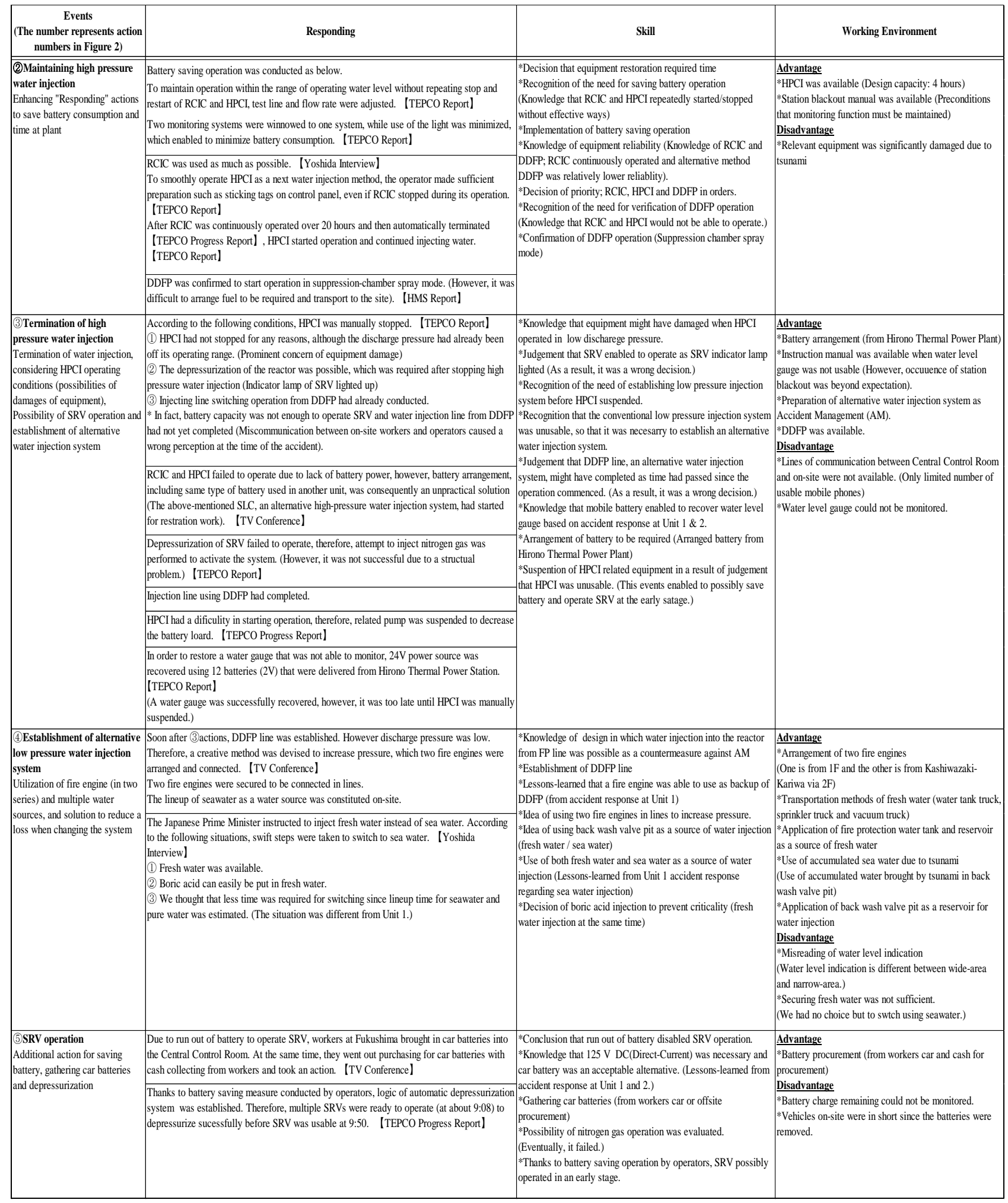

\section{4. 背後要因モデルによる“Responding”の検討}

ここでは，図 2 並びに表 2 を参照して，Responding の発揮を生んだ背後要因のうち，人材育成として考慮す心゙ き Skill と Attitude に着目し，教訓を導出する.また, Working Environmentについては人材育成に考慮すべき点に ついて検討する. 


\section{4・1 1F 事故への “Responding” に見る Skill}

(1) 各行為群に含まれる Skill の分析

行為群(1)のSLC の復旧では, SLC が安全系であり信頼性が高く, 高圧系の代替として期待できるという基本知 識に加え, 注入容量が少ないため別途水源を用意する必要があるといった設備の特徵を踏まえた Responding が発 揮されている. 電源を供給するために，ダメージを受けていない 4 号機設備の活用を進める Responding を発揮し たが，1 号機の爆発で設備を復旧することはできなかった。しかしながら，本行為群の目的は，原子炉の減圧が できない可能性に備えたリスク対策であり，どの選択肢にもリスクが伴う中で，現場がさまざまなリスクの顕在 化に備えようとする基本姿勢が伺える.

行為群(2)の高圧注水継続では，生き延びた直流電源で高圧注水をできるだけ長期間継続させるために，通常で あれば注水系統が水位の回復／低下に伴い起動停止を繰り返し，バッテリーを消費するところを，テストライン などを組み合わせることでバッテリー消費を回避した. 加えて, 監視系統もリスクを取って最低限の 1 系統に絞 り込みを行っている．また，当該系統が注水に寄与できないと判断した後は，線量が高く厳しい環境の中で，周 辺機器を含めて最大限負荷を落としている。このようなバッテリーの節約が，バッテリーの延命に繫がり，注水 の継続や早期の減圧実施に寄与した。

行為群(3)の高圧注水の停止では，注水継続をしなければならない中，すでに運転領域を超えていた HPCI が破 損するリスクが顕在化することを回避し, 機器保護を行いつつ次の手段に切り替えるというシナリオを選択した. 結果は, 機器保護には成功したものの, 次の注水手段への切り替えが実行できず, 注水が停止するというリスク が顕在化している。このリスクに対する Anticipating を保有していただけに, その回避手段およびその準備状況を 組織として共有するべきであった.

低圧の代替注水を確立する(4)の行為群では, (3)て確立できなかった注水ラインを構築した. 原子炉の圧力が 下がりきらないリスクに対する適切な Anticipating が，注水圧力を高めるための消防車を直列につないだ注水 インの構成という臨機の Responding の発揮に繋がっている.また，長期戦の Anticipating により，淡水から海水 の切替えを含めた水源の確保の Responding が発揮されている.

また，行為群(5)の減圧操作に関しては，先行号機の事故対応に Learning を発揮し，直流電源確保対策として， 社員の車のバッテリーを活用した Responding を臨機に発揮した. (2)でのバッテリー延命の応急策が功を奏し，減 圧に成功するとともに, 注水の確立を達成している.

（2）「想定を超えた設計基準外事象」における Responding の発揮に必要な Skill

通常の設計事象，あるいは想定を超えない設計基準外事象の範囲では，「人」に求められる Skill は，定められ た手順に従って誤りなく行動ができるかといったシステムを構成する一つの要素としての役割である.しかし， 表 2 にまとめた通り, 注水の回復という $1 \mathrm{~F}$ 事故の現場対応の 1 つの事例を見ても, 様々な選択肢について, リ スクのトレードオフを限られた情報と時間の中で考慮しつつ, 臨機に Responding を発揮したこと, 時に実際にリ スクが顕在化し，新たな対応を必要とする行為群も存在していることが確認できる．これらは，リスクを避けつ つも成功を獲得するために，考えられる選択肢にそれぞれ注力しなければならない緊急時対応の実態を示してお り，このような Skill は，通常の設計事象，あるいは想定を超えない設計基準外事象において求められる Skill と は異なっている．政府事故調の委員長である畑村は，1F 事故現場で求められた Skill ついて，「（前略）今回の 事故では不適切な対応が多々あったが，他方，たとえば周囲にあった自動車のバッテリーをかき集めて応急の電 源として計測器を動かし, 必要最小限のデータを収集するなど, 臨機の工夫と判断で事態を打開するための努力 がなされた例も多い，そのような対応は，関与した人たちが，実現したい事柄に向けて自ら考え，判断し，行動 することによって可能となったものである.」(東京電力福島原子力発電所における事故調査・検証委員会, 2012b) と述べているが，1F 事故の現場では，「想定を超えた設計基準外事象」に必須となる Skill を要した.

このような $1 \mathrm{~F}$ 事故の事例を見ても，「想定を超えた設計基準外事象」における Responding には，既存の設備や マニュアルをそのまま適用できるか不確実であり, 過酷な Working Environment のもと, 限られた時間の中で，状 況判断に基づく創意の発揮などの応用動作も必要である可能性が高い. また，既存の設備やマニュアルが適用で きない事象では，存在する選択肢のいずれもがリスクを伴うと考えるのが適切であろう。どちらもリスクを有し 
ている選択肢の中で, 最善と考える選択肢を実行するには, その行為の実行 Skill と同時に, 選択した行為のリス クの顕在化についても Anticipating を発揮し, 目標とする成功を獲得するための手段を講じる Skill も同時に保有 することが必要になるという，新たな教訓が導かれる.

\section{$4 \cdot 2$ 1F 事故の “Responding”に見る Attitude とその要素}

（1）事故現場の行為者に関する記述

3 号機の注水回復事象の分析からは，多くの困難を伴う状況下において，システムが受けたダメージからの回 復や更なる破局を防ぐために必要な能力を有していたのは「人」であったことがわかる１F 事故について分析し た INPO（Institute of Nuclear Power Operations）は，Special Reportに，「想定外かつ複雑で多大なストレスを伴う 状況にあって，発電所職員は，津波以降，重要な安全機能を復旧する作業において，個人の重要な責務，状況を 回復しようとする力（resilience），創意ある対処をした。地震と津波によって広範に荒廃し死亡者が出たにもか かわらず，家族の安否が不明だったことをはじめとして，悪天候，休息・食料・水の不足といった困難な状況下 でこれらの対応が行われた。」（INPO, 2012）と記しているが，このような指摘は，我々に改めて「人」の存在に ついて考えることを求めていると受け止めるべきと考える.

さらに, 当時現地の緊急時対策本部長は, 吉田調書の中で, 次のような発言をしている. 「私は, ここの発電 所の発電員, 保修員は優秀だと思います. 3 発電所を見ても, 今まで一番トラブルも経験していますから, 肌身 で，協力企業だけを使うんではなくて，自分からでも作業をしてきた経験がありますから，これだけのことをで きたんだと思います.」，「（前略）瓦碩の撤去, 必要最小限の注水のためのホースの取替えだとか, 注水の準 備に対応してくれと頭を下げて頼んだんです，そうしたら，本当に感動したのは，みんな現場に行こうとするわ けです.」（政府事故調査委員会, 2011a）これらの発言には, トラブルをこれまでも多く経験し, 緊急時への対 応姿勢が鍛えられていた職員の存在や，高放射線量かつ建物が爆発するという危険な環境の中で，飛び散った高 污染のがれきの撤去や，原子炉への注水ラインを確保するための消防車の配備，ホースの敷設など，原子炉への 注水を回復させるために作業員が見せた Responding の裏にある強い“Attitude”が滲み出ている.

しかしながら，既存の事故調查のように事故原因の究明に着目した分析では，上手くいかなかった事象が切り 出されるために, 人が犯したエラーや, 判断を過った行為が取り上げられる. そのため, 主要な報告書では, Attitude に関する記述はあるものの, それらを「想定を超えた設計基準外事象」において安全を確保するための教訓とし て取り上げてはいない. 一方, レジリエンスエンジニアリングの手法を参照し, 背後要因を含めた事象の分析を 行うことで，成功やダメージからの回復に着目する意義を明らかにすると同時に，緊急時における安全を支える 人材に必要な Responding や，それを支える “Attitude”の重要性を，教訓として導出することを可能とした.

\section{(2) Attitude $の$ 要素}

表 2 の項目から Attitude を外したことからもわかるとおり, Attitude は, 設備操作の時系列からは直接読み取れ ない情報である.だが， $1 \mathrm{~F}$ 事故の現場は，12 日の 0:30 に現場調查中社員 2 名の所在不明を発表，15:36には 1 号 機の原子炉建屋の爆発およびこれに伴う負傷者の発生，16:17 には敷地境界放射線異常上昇（原子力災害対策法 第 15 条通報事象)に至るという厳しい環境にあった. よって, Attitude は, 発電所で行われたさまざまな Responding に共通していたと考え, $1 \mathrm{~F}$ 事故現場における行為者個人の心理的な表現に関するデータを収集した (高橋, 2015 ; 東京電力株式会社, 2012b）. これらを分析した結果から, Attitude の要素の抽出を行った.

運転員から「なにもできないなら，ここにいる意味があるのか」と問われた当直長が，「運転員が制御室を離れ るということは, 原子炉の制御を諦めるということである. すなわち, 我々を信じて避難している地元の人たち, みんなの家族を見捨てるということだ. 最後になんとかしなくちゃならないのは現場の近くにいるわれわれだ. だから簡単に離れるわけにはいかない.」と話し，深々と頭を下げたという事例がある（高橋，2015）。ここから は, 「使命感」「リーダーシップ」,「家族や友人を守りたいという思い」,「地元／地域への愛着」といった要素が 抽出できる.また，「私は何でもやります，私は発電所に突っ込む覚悟です．何かやらなければならないことが あれば，遠慮しないで言ってください，最後は運転員の意地を見せたいんだ。」（東京電力株式会社，2012b）と いう言葉からは，「使命感」，「フォロワーシップ」，「誇り」といった要素が抽出できる. 事故当時非番で避 難していた運転員が, 「12 日に避難しろということで, 避難し始めたんですけど, やっぱりどうしても俺, 会社 
が心配だからと言って, 途中で降りて歩いて戻った. シャットダウンを入れるのを手伝いに行ってくるから位に 家族に言って，家まで歩いて，車に乗って発電所に向かった．」（東京電力株式会社，2012b）といった報告があ るが, ここからは，「使命感」や，自らの働く，あるいは過去に携わったプラントに愛情や愛着を持つことを意 味する「マイプラント意識」といったものが読み取れる，さらに，協力企業の作業員も強い Attitude を示してい る.「協力企業の社員さんが，社長からは戻るよう言われていたのに，我々みんな（東京電力社員）*で何とか 発電所を守るために一生懸命対応している姿を見て，「私は帰れない」と泣いて残ってくれた.」（東京電力株 式会社，2012b）「プラントメーカーとしての使命と，（発電所長の）*吉田昌郎があれだけ一生懸命がんばって いるのに見捨てるわけには行かない，そんな思いでしたね。」（高橋，2015）といった言葉からは，組織を超え た「一体感」，「使命感」が強く表れている。（*著者の加えた注記）

このような現場の行為者の言葉から, Responding の発揮を生んだ背後要因の Attitude として, 使命感, マイプ ラント意識・誇り，リーダーシップ・フォロワーシップ，一体感，家族や友人を守りたいという思い，地元／地 域への愛着，という6つの要素が抽出できる（大場他，2014）。

\section{$4 \cdot 3$ Working Environment の検討}

$3 ・ 2$ において, Working Environment が「Skill やAttitude を支える要因」であり, 技術システムの安全を担う組 織はこれらについても理解し, 醸成すべきでものであると述べたが, 「想定を超えた設計基準外事象」が顕在化し た $1 \mathrm{~F}$ 事故の現場の Working Environmentについて，レジリエンスエンジニアリングを参照し，検討する.

表 2(1に記載したとおり, 現場の Working Environment を確保する上で要となった設備として, 中越沖地震の教 訓として設置された免震重要棟を挙げることができる.免震重要棟は, 作業員を放射線や建物の爆発から防護し, 食事, 睡眠の確保, 医療の提供を可能とし，さらに棟内に設置された発電所対策本部が，TV 会議システムを通 じて本店本部やオフサイトセンター等と繋がったことから, 事故対応に必要な連携を生む重要なコミュニケーシ ヨンを図ることができた。これらのコミュニケーションが図れたことで実現できたことの一つが消防車を活用し た海水注入である.このことからも, 直接事故対応を行わない免震重要棟の存在が, 現場で発揮された Responding の背後要因にある Skill や Attitude を支えていたことは明らかであり, 図 2 のモデルも理解できよう.

リソースに関しては，表 2 にも記載しているが，特に TV 会議の会話から十分でなかったものを抽出すること ができる. 電源車や消防車等への燃料不足は代表的であるが，SRV を作動させるために車のバッテリーを活用し たことから現場に行く車両が不足したこと，防護服が足りず現場作業に制約が出たことなど，人の能力を活か寸 ためにも, リソースの充実は必要であることも重要な教訓の一つである.

さらに, 既存の事故調查では対策が不十分とされているアクシデントマネジメントについては, 低圧系代替注 水の設備的対策, 並びに手順が準備されていたことが, 消防車や海水の活用といった人の創意の発揮と合わさり, 原子炬への注水を実現した. このようにアクシデントマネジメントが有効に機能したことで注水が確保できたと いう評価は, 良好事例に着目するレジリエンスエンジニアリングの視点だからこそ導出できるものであろう. 尚, アクシデントマネジメントの効果について, 吉田も「アクシデントマネジメントで FP から原子炬に注水すると いうライン構成ができていなかったら，もうどうしようもなかったですね.」(政府事故調查委員会, 2011a) と発 言している.

Working Environment は，適切な Responding の発揮に必要な Skill や Attitude に影響を与えるものである.よっ て, 通常, どのような能力を育成す心゙きかという検討（人材育成）の対象にはならないが，技術システムの安全 を担う組織が, Working Environment を整えること, さらにいえば, Working Environment の重要性を認識し, 適切 な Working Environment を作れる人材を育成することが必要である.

本研究は，機械学会報告に基づいて検討していることから，Working Environment に関しての人材育成の考察は 行わないが，「想定を超えた設計基準外事象」の備えには, Working Environment の重要性を十分に考慮する必要 がある. $1 \mathrm{~F}$ 事故時も, 事故現場で対応する者を加害者とみなし, Working Environment の充実に対して否定的な意 見も散見されたが, 事故の影響を小さくするためにも, 事故収束や回復は必要な作業である. 本研究の分析に基 づき, Responding を十分に発揮できる Working Environmentについての検討が必要である.

\section{5. 人材育成への教訓と考察}


前章までの評価を踏まえ，「想定を超えた設計基準外事象」において，適切な Responding を発揮できる人材育 成について, 個人が備えの主体となる Skill とAttitude についての教訓をまとめ, 組織としての人材育成につな げるための考察を行う.

\section{$5 \cdot 1$ 「想定を超えた設計基準外事象」における Responding の発揮に必要な Skill の育成}

(1) 人の役割の再定義 : 過誤し得る存在から安全を実現する存在へ

1 章で述べたとおり, ISO/IEC Guide51 では安全を「許容不可能なリスクから解放されていること」と定義し， 「危険（Risk)」を許容可能なレベルまで取り除くことで安全を達成できるという前提の下，過去の事故事例等か ら，人はエラーを起こす「システムの安全性を劦かす要素」として位置づけている．そのため，安全のためには ヒューマンエラーの低減やオートメーション化が必要とされた。このような評価の中では，人は，「人的過誤率

(Human Error Probability)」という言葉に代表されるように, 過誤し得る存在として扱われている.さらに, 機械 学会報告の(A)「認識科学に立脚した設計科学」に指摘されるような技術システムに想定されるリスクに対して, その条件の下でシステムが正常に作動するべく適切な設計基準を作成および実行する能力の醸成の背景も, 同じ 考え方であろう。安全の実現には, 適切な設計基準を作成した上で, 実行の手順を定め, 実行者となる「人」が 手順に従った対処を精度よく実行できるための教育・訓練が有効となる.

しかし，ヒューマンエラーの防止は安全確保の上で必要であるが，人を過誤し得る存在として扱うような評価 には，1F 事故現場でみられたような創意を発揮する対処の実行者であることは含まれていない。学会事故調も, 過酷事故一の対応であるアクシデントマネジメントにおいて，柔軟な対応の必要性を指摘しているが，本研究の 目的である機械学会報告のBを実現させる「想定を超えた設計基準外事象が起きても，受け入れがたい損害が発 生しないような対応ができる能力」を醸成するには,「人」を, 過誤し得る存在としてだけではなく, 創意を発揮 した対処によって安全を実現する存在と位置づけ，その上でその創意の発揮を可能にする人材の育成と条件の整 備を目指すべきであろう。

（2）対処の選択基準の設定：いずれの選択肢もリスクがある中でどう意思決定すべきか

手順がなく，創意を発揮した対処が必要となるような想定を超えた設計基準外事象における安全の考え方も整 理すべきである. たとえば， $1 \mathrm{~F}$ 事故現場において行われた判断の一つである原子炉への海水注入の判断（行為群 (4)，(5)）と，3 号機の HPCI 停止（行為群(3)）を比較してみよう. 淡水が枯渇する中，プラントの再起を不可能 とする海水注入に踏み切った前者は, 原子炉の状態を改善することができた. 他方, 機器の保護と注水停止リス クのトレードオフの中で, 機器の保護を優先した後者は, 原子炉の状態悪化を招いた. このことから，この $2 つ$ の行為は，いずれも事態を収束，回復を目指した創意を発揮した対処であり，柔軟な対応事例であるにもかかわ らず，政府や国会事故調の評価は大きく異なっている，リスクがある選択肢の中で行われる行為の結果は，その 行為のみならずさまざまな要因の影響を受ける想定を超えた設計基準外事象が顕在化したときに柔軟な対応を求 めるのであれば, 人材育成の場では, その拠り所となる安全の考え方や指針を提示することが必要であろう.さ らに，それを機械学会報告のCで求めている「技術の社会技術化科学」の中で扱う必要もある. 現在の事故調査 のように, 組織における行為の評価を, 後から判明する結果によるものではなく, 行為実施時の安全の考え方や 指針に照らし合わせて行う方向にすることが，より多くの「想定を超えた設計基準外事象」において適切な Responding の発揮を生み出すために，肝要である.

具体的な指針の一例として, 良好事例への着目と, 4 つのコア能力の重要性を指摘しているレジリエンスエン ジニアリングを参照する方法が考えられる. 近年 Hollnagel は, レジリエンスエンジニアリングが目指す安全概念 として,「安全は変化する条件下で成功する能力」であると定義し, 人を「システムのしなやかさ, 回復力に必 要な資源」と位置づけると同時に, 達成すべき目標を「許容される結果が最大化される状態」としている (Hollnagel, 2014）。これは，成功を高める原動力は「人」にあるという基本認識に基づいた概念であるが，1F 事故の現場で 人や組織に必要とされた Respondingに係る Skill を見事に表現している.

このような概念に基づいて「想定を超えた設計基準外事象」において適切な Responding を発揮できる人材の具 体的な育成計画を考えるならば，結果ではなく，過程（プロセス）評価を用いることや，いかに事態を収束，回 
復を実現する柔軟な対応を見出すかといった観点が新たに導入されることになろう．本研究ではレジリエンスエ ンジニアリングの 4 つのコア能力のうち Responding に着目した評価を実施したが，他のコア能力である Anticipating, Monitoring との連携も, リスクの顕在化に適切な Responding を発揮する重要な視点となってくる. 本研究のアプローチでもある, 既存の事故報告書では扱われていなかった現場の多くの行為群への Learning の発 揮も欠かせない要素である.

\section{$5 \cdot 2$ Attitude の醉成}

(1) 重要性の認識

これまで, 原子力発電所の運転員の育成事業は, 国際原子力機関（IAEA: International Atomic Energy Agency） の示すガイドラインに沿って実施されており，その中で，部下のやる気を引き出すのは上位職の役割とされてき

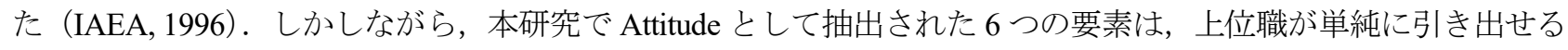
ものではない. 福島第二原子力発電所の対応事例では, 緊急時の作業員の家族の状況確認や, 必要な措置を講じ る必要性が指摘されているが（川村, 奈良林，2016）, ここで示した Attitude の要素は, それらの位置づけをより 明確に認識させるものでもある.

（2）要素の理解と醸成プログラムへの留意点

$1 \mathrm{~F}$ 事故という，想定を超えた設計基準外事象において Responding を発揮した現場の行為者から抽出された Attitude の要素から，このような事象において Responding を発揮するための Attitude の醸成の検討をすれば，必 然的に, 組織として対応す心゙き地元との雇用関係や, 個人としての要素も大きいと考えられる地域（発電所）で の通常業務，生活を通じて時間をかけて培うことの重要性が見えてくる．現在はさまざまな分野で人材育成の必 要性が問われ，それに呼応する教育プログラムが設計されているが, Attitude に関する人材育成は, 日頃の職場環 境, 生活環境等総合的な活動の在り方に基礎があり, 組織が直接実施できるものや, 組織が個人をサポートしつ つ間接的に達成するものが存在している．また，その醸成には時間を要することを理解する必要がある．これら は新たな教訓といえる.

(3) 醸成範囲の検討

1,3 号機と同様な水素爆発への Anticipating の発揮により実施された, 5, 6 号機原子炉建屋の水素排気用の穿孔 事例では，日常の業務の中で，作業を実施した協力企業社員と東京電力社員との間に構築された信頼関係が，緊 急時の非常に厳しい環境下での作業遂行につながっている（Yoshizawa et al., 2016）。この事例や4.1（2）で示した 協力企業社員のエピソードから, Attitude の醸成を考慮すべき範囲は, IAEAの規定している発電所の運転員のみ ならず，他の部門の電力職員や協力企業を含めて考えておくべきものであることも，新たな教訓として導出でき る.

\section{$5 \cdot 3$ 既存の事故調查の教訓との違い}

「事故の原因究明と再発防止」を目的とした既存の事故調查では, 人や組織に係るものとして, 災害時の体制, 訓練, 責任分担などが教訓として指摘されている.しかし,「想定を超えた設計基準外事象」への適切な Responding を発揮する要素としては, 訓練や権限配分といった指摘に留まっているのが実態である. 一方, 事故対応を, レ ジリエンスエンジニアリングを参照した本研究では, 成功や回復に係る行為群に着目した分析を行うことで,「想 定を超えた設計基準外事象」において Responding を発揮するためには，強い Attitude と創意を発揮した対処がで きるSkill が必要であることを教訓として導出した. これらは, 既存の事故調査の「失敗した行為群」に着目した 分析の結果から導かれる教訓とは明確に異なっており, 同一事象からの新たな教訓の導出といえる.

このように, 既存の事故調查に加え, レジリエンスエンジニアリングの考え方を導入することで, 事故対応を, 失敗, 成功（回復）といった行為群の集合体であるという視点で俯瞰的に捉えることができ，総合的な Learning の涵養にも貢献できると考える.

\section{6. 結 言}


本研究では，機械学会報告にある人材育成の課題のひとつである「想定を超えた設計基準外事象」に対し，残 存リスクが顕在化しても，受け入れがたい損害が発生しないような対応ができる能力を高めるために，想定を超 えた設計基準外事象である $1 \mathrm{~F}$ 事故の過酷事故対応に基づき，レジリエンスエンジニアリングの考え方を用いて 検討した. 本稿の分析により, $1 \mathrm{~F}$ 事故の現場の対応は, さまざまな行為の総体であること, それらの行為には, 成功したものも失敗したものもあることが明らかになると同時に，具体的に既存の事故報告書では注目されてい ない「事象の進展を防いだ Responding」も明確にすることができた. また，そのような Responding のいずれもが，

「人」の持つ柔軟な創意を発揮したものであることも明らかとなった．さらに，先行研究を踏まえて作成した背 後要因の構造化モデルを用いることで, これらの Responding の背後要因が抽出でき, 緊急時における Attitude $の$ 重要性を新たな教訓として導出した. Skill の具体例からは, 「想定を超えた設計基準外事象」では, 臨機に Responding を発揮する上でしばしばリスクを伴う判断が求められており, 選択に伴うリスクに対し, 適切に Anticipating を発揮し，それを Responding の発揮につなげることの必要性を教訓として抽出した.

これらの結果を用いて, 今後も起こりうるであろう「想定を超えた設計基準外事象」に対し，人材育成として 考慮すべき Attitude と Skill の要件を明確にした. 得られた結果を人材育成に活かすために, Attitude を醸成する 通常時における職場の業務環境への配慮, Skill として応用力を引き出すための新たな安全概念や現場において行 われるさまざまな行為の評価手法の必要性といった, 既存の事故調査とは異なる新たな教訓の導出に成功した. このようなことから，既存の事故調査とレジリエンスエンジニアリングの視点は，事象分析において異なる着眼 点を与えており，両方の視点からの教訓抽出アプローチが必要であることを明示した.

今後, レジリエンスエンジニアリングの応用領域として, 本研究で実施したような事例分析を通じた新たな教 訓導出手法およびその有用性についても注目していきたい.

\section{文献}

日本原子力学会ヒューマン・マシン・システム研究部会 東京電力(株福島第一原子力発電所事故調査検討小委員 会, ヒューマンファクターの観点からの福島第一原子力発電所事故の調査,検討 (2015), pp.36-42 (online), available from <http://www.aesj.or.jp/ hms/report/hms_report_1F_accident.pdf $>$, (参照日 2017 年 4 月 10 日).

日本原子力学会, 福島第一原子力発電所事故その全貌と明日に向けた提言, 丸善出版 (2014), pp.25-29, pp.167-175, pp.280-283.

産業競争力貏談会, レジリエント・ガバナンス, 研究会最終報告, (2013), p.2 (online), available from $<$ http://www.cocn.jp/thema65-L.pdf $>$, (参照日 2017 年 5 月 13 日).

Heikkilä, J., Uusitalo, T., Lappalainen, J. and Rantanen, E., Proactive and flexible safety management-resilience in Finland, 5th International Conference Workingonsafety.net (2010).

Hollnagel, E. and Woods, D.D., Epilogue, resilience engineering precepts. In Hollnagel, E., Woods, D. D. and Leveson, N., Resilience engineering : Concepts and precepts, ASHGATE (2006), pp.347-358.

Hollnagel, E., 小松原明哲[監訳], 社会技術システムの安全分析 FRAM ガイドブック，海文堂(2013), pp.26-28.

Hollnagel, E., The four cornerstones of resilience engineering. In Nemeth C.P., Hollnagel E. and Dekker, S., Preparation and restoration, Resilience engineering perspectives, Vol.2, ASHGATE (2009), pp.117-121.

Hollnagel, E., Prologue, The scope of resilience engineering. In Hollnagel, E., Pariès, J., Woods, D. D. and Wreathall, J., Resilience engineering in practice: A guidebook, ASHGATE (2011).

Hollnagel, E., Safety-I and safety-II, The past and future of safety management, ASHGATE (2014), pp.145-148.

IAEA (International Atomic Energy Agency), Technical reports series No. 380 (1996), pp.18-32.

INPO (Institute of Nuclear Power Operations) Special report, Lessons learned from the nuclear accident at the Fukushima Daiichi nuclear power station (2012), p.3.

東京電力福島原子力発電所における事故調査・検証委員会, 最終報告書 (2012a), pp.36-40, pp.363-366, 資料編 pp.263-292.

東京電力福島原子力発電所における事故調査・検証委員会, 最終報告書 (2012b), 委員長所感 p.448.

東京電力福島原子力発電所における事故調査・検証委員会, 中間報告書 (2011), pp.170-192.

政府事故調査委員会, ヒアリング記録: 吉田昌郎聴取結果 平成 23 年 7 月 29 日，事故時の状況とその対応につい

$\tau$ (2011a) (online), available from <http://www8.cao.go.jp/genshiryoku_bousai/fu_koukai/pdf_2/051.pdf>, (参照日 
2017 年 4 月 10 日).

政府事故調査委員会，ヒアリング記録 : 吉田昌郎聴取結果 平成 23 年 8 月 8,9 日, 事故時の状況とその対応につ いて 4 (2011b) (online), available from <http://www8.cao.go.jp/genshiryoku_bousai/fu_koukai/pdf_2/077_1_4.pdf >, (参照日 2017 年 4 月 10 日).

川村慎一, 奈良林直, 東日本大震災における福島第二原子力発電所の緊急時対応の教訓を反映した原子力緊急時 マネジメントシステムの改善，日本原子力学会和文論文誌，Vol. 15, No. 2 (2016), pp.84-96.

北村正晴，レジリエンスエンジニアリングが目指す安全 Safety-II とその実現法, IEICE fundamentals review Vol.8 No.2 (2014), pp.84-95.

Komatsubara, A., Resilience management system and development of resilience capability on site workers, Proceedings of the fourth resilience engineering symposium (2011), pp.148-154.

宮崎知己，木村英昭，福島原発事故記録チーム編，解説 : 福島原発事故 東電テレビ会議 49 時間の記録, 岩波書 店 (2013), pp.2-96.

東京電力福島原子力発電所事故調査委員会, 報告書 (2012), pp.166-168.

大場恭子，吉澤厚文，北村正晴，福島第一原子力発電所事故をふまえた組織レジリエンスの向上(II)—Attitude の 構成要因とその醸成一，日本機械学会 2014 年度年次大会予稿集 (2014), Paper No. G2010103.

佐野信也，谷川武，重村淳，佐藤豊，吉野相英，藤井千代，立澤賢孝，桑原達郎，立花正一，野村総一郎，復興 ストレスの諸相一福島原発勤務員へのメンタルヘルス支援活動一，精神経誌，Vol.114，No.11(2012), pp.12741282.

高橋秀樹，共同通信社原発事故取材班，全電源喪失の記憶，祥伝社 (2015), pp.128-129, p.195.

The International Organization for Standardization and the International Electrotechnical Commission, Safety aspectsguidelines for their inclusion in standards, Guide51 Chapter 3.14 (2014).

日本機械学会福島原発事故の教訓から学ぶ工学の原点と社会的使命検討委員会, 報告「福島原発の教訓から学ぶ 工学の原点と社会的使命〜安全・安心社会構築に向けて〜」 (2013), pp.10-23 (online), available from< https://www.jsme.or.jp/shinsai3.11/wg4report.pdf>, (参照日 2017 年 4 月 10 日).

東京電力株式会社, 福島原子力事故発生後の詳細な進展メカニズムに関する未確認・未解明事項の調査・検討結 果～第 4 回 進 捗 報告 (2015)，資 料 3-3，3-4，3-5 (online), available from $<\mathrm{https}$ //www4.tepco.co.jp/cc/press/2015/1264445_6818.html>，（参照日 2017 年 4 月 10 日).

東京電力株式会社，福島原子力事故調査報告書，中間報告書 (2011), pp.56-61, 別紙 pp.30-38, 添付 pp.7-8.

東京電力株式会社，福島原子力事故調査報告書 (2012a), pp178-203，添付 pp.90-103.

東京電力株式会社，福島原子力事故調査報告書 (2012b)，別紙 2, 別添「現場の声」.

Yoshizawa, A., Oba, K. and Kitamura, M., Lessons learned from good practices during the accident at Fukushima Daiichi nuclear power station in light of resilience engineering, Elsevier Science Direct, IFAC-Papers On Line, 49-19(2016), pp. $245-250$.

\section{References}

Atomic Energy Society of Japan, Human Machine Systems Research Group, Investigation and consideration of Fukushima Daiichi nuclear power plant accident from the perspective of human factor (2015), pp.36-42 (online), available from < https://www.jsme.or.jp/shinsai3.11/wg4report.pdf>, (accessed on 10 April, 2017), (in Japanese).

Atomic Energy Society of Japan, Tokyo Electric Power Company Fukushima Daiichi Nuclear Power Plant Accident Investigation Committee, Future recommendations and full picture of Fukushima Daiichi nuclear power plant accident, Maruzen Publishing (2014), pp.25-29, pp.167-175, pp.280-283 (in Japanese).

Council on Competitiveness-Nippon, Resilient governance, Study Group Final Report (2013), p.2 (online), available from $<$ http://www.cocn.jp/thema65-L.pdf $>$, (accessed on 13 May, 2017), (in Japanese).

Heikkilä, J., Uusitalo, T., Lappalainen, J. and Rantanen, E., Proactive and flexible safety management-resilience in Finland, 5th International Conference Workingonsafety.net (2010).

Hollnagel, E. and Woods, D.D., Epilogue: resilience engineering precepts. In Hollnagel, E., Woods, D. and Leveson, N., Resilience engineering: Concepts and precepts, ASHGATE (2006), pp.347-358. 
Hollnagel, E., translation supervised by Komatsubara, A., FRAM: The functional resonance analysis methods - modelling complex socio-technical systems, Kaibundo Publishing (2013), pp.26-28 (in Japanese).

Hollnagel, E., The four cornerstones of resilience engineering. In Nemeth C.P., Hollnagel E. and Dekker, S., Preparation and restoration, Resilience engineering perspectives, Vol.2, ASHGATE (2009), pp.117-121.

Hollnagel, E., Prologue, The scope of resilience engineering. In Hollnagel, E., Pariès, J., Woods, D. D. and Wreathall, J., Resilience engineering in practice: A guidebook, ASHGATE (2011).

Hollnagel, E., Safety-I and safety-II: The past and future of safety management, ASHGATE (2014), pp.145-148.

IAEA (International Atomic Energy Agency), Technical reports series No. 380(1996), pp.18-32.

INPO (Institute of Nuclear Power Operations), Special report, Lessons learned from the nuclear accident at the Fukushima Daiichi nuclear power station (2012), p.3.

Investigation Committee on the Accident at the Fukushima Nuclear Power Stations of Tokyo Electric Power Company, Final report (2012a), pp.36-40, 363-366, Appendix pp.263-292 (in Japanese).

Investigation Committee on the Accident at the Fukushima Nuclear Power Stations of Tokyo Electric Power Company, Final report(2012b), p.448 (in Japanese).

Investigation Committee on the Accident at the Fukushima Nuclear Power Stations of Tokyo Electric Power Company, Interim report (2011), pp.170-192 (in Japanese).

Investigation Committee on the Accident at Fukushima Nuclear Power Stations of Tokyo Electric Power Company, Interview records, Results of interview with Masao Yoshida (2011a), 29 July (online), available from $<$ http://www8.cao.go.jp/genshiryoku_bousai/fu_koukai/pdf_2/051.pdf>, (accessed on 10 April, 2017), (in Japanese).

Investigation Committee on the Accident at Fukushima Nuclear Power Stations of Tokyo Electric Power Company, Interview records, Results of interview with Masao Yoshida (2011b), 8,9 August (online), available from $<$ http://www8.cao.go.jp/genshiryoku_bousai/fu_koukai/pdf_2/077_1_4.pdf>, (accessed on 10 April, 2017), (in Japanese).

Kawamura, S. and Narabayashi, T., Improved nuclear emergency management system reflecting lessons learned from the emergency response at Fukushima Daini nuclear power station after the great east Japan earthquake, Transactions of the Atomic Energy Society of Japan (in Japanese), Vol. 15, No. 2 (2016), pp.84-96.

Kitamura, M., New concept of safety-II pursued and implemented by resilience engineering, IEICE Fundamentals Review Vol.8 No.2 (2014), pp.84-95 (in Japanese).

Komatsubara, A., Resilience management system and development of resilience capability on site workers, Proceedings of the fourth resilience engineering symposium (2011), pp.148-154.

Miyazaki, T., Kimura, H. and Fukushima Nuclear Accident Record Team, Meltdown countdown: 49 critical hours of the TEPCO teleconference, Iwanami Shoten (2013), pp.2-96 (in Japanese).

National Diet of Japan Fukushima Nuclear Accident Independent Investigation Commission, The official report (2012), pp.166168 (in Japanese).

Oba, K., Yoshizawa, A. and Kitamura, M., Enhancement of organizational resilience in light of the Fukushima Daiichi nuclear power plant accident (II) -promoting of attitude building measures-, The Japan Society of Mechanical Engineers, Proceedings of the 2014 Annual Conference (2014), G2010103 (in Japanese).

Sano, S., Tanigawa, T., Shigemura, J., Satoh, Y., Yoshino, A., Fujii, C., Tatsuzawa, Y., Kuwahara, T., Tachibana, S. and Nomura, S., Complexities of the stress experienced by employees of the Fukushima nuclear plants, Psychiatria et neurologia Japonica, Vol.114, No.11 (2012), pp.1274-1282 (in Japanese).

Takahashi, H. and Kyodo News Nuclear Accident Coverage Team Editor, Remembrances of the loss of all power, Shodensha (2015), pp.128-129, p.195 (in Japanese).

The International Organization for Standardization and the International Electrotechnical Commission, Safety aspectsguidelines for their inclusion in standards, Guide51 Chapter 3.14 (2014).

The Japan Society of Mechanical Engineers, Learning social mission of engineering from the accident of Fukushima no. 1 nuclear power plant -toward reliable and safety society-(2013), pp.10-23 (online), available from < https://www.jsme.or.jp/shinsai3.11/wg4report.pdf>, (accessed on 10 April, 2017) (in Japanese).

Tokyo Electric Power Company, The 4th progress report on the investigation and examination of unconfirmed and unresolved 
issues on the development mechanism of the Fukushima Daiichi nuclear accident (2015), Attachment 3-3, 3-4, 3-5 (online), available from <https://www4.tepco.co.jp/cc/press/2015/1264445_6818.html >, (accessed on 10 April, 2017) (in Japanese).

Tokyo Electric Power Company, The Fukushima nuclear accidents investigation interim report (2011), pp.56-61, Appendix pp.30-38, Attachment pp.7-8 (in Japanese).

Tokyo Electric Power Company, The Fukushima nuclear accidents investigation report (2012a), pp.178-203, Attachment pp.90-103 (in Japanese).

Tokyo Electric Power Company, The Fukushima nuclear accidents investigation report (2012b), Appendix 2, Attachment "voices from the field", (in Japanese).

Yoshizawa, A., Oba, K. and Kitamura, M., Lessons learned from good practices during the accident at Fukushima Daiichi nuclear power station in light of resilience engineering, Elsevier Science Direct, IFAC-Papers On Line, 49-19 (2016), pp.245-250. 